\title{
T24 - Electrocardiógrafo registrador de datos con comunicación inalámbrica a computador
}

\author{
Yeser A. Morales*, Keller Jirón \\ Universidad Nacional de Ingeniería, Nicaragua
}

*Autor al que se dirige la correspondencia: moralesalfredo133@gmail.com

\section{Resumen}

$\mathrm{U}$ n electrocardiógrafo es un instrumento utilizado para la detección y diagnóstico de anormalidades en el funcionamiento del corazón, generalmente son costosos y en el país muy pocos son portátiles lo cual dificulta tener información del ritmo cardiaco ya sea cuando se traslada un paciente a una clínica u hospital o cuando el paciente necesita tener información frecuente del mismo. Este articulo describe el procedimiento seguido, y los resultados obtenidos, al implementar un electrocardiógrafo registrador de datos con capacidad de enviarlos a una computadora utilizando el protocolo de comunicación bluetooth. En la implementación del electrocardiógrafo se utilizó la tecnología de microcontroladores y el software Labview para mostrar en la pantalla el electrocardiograma. Los datos son almacenados en una memoria EEPROM lo cual permite su reproducción para posteriores análisis.

Palabras claves: Electrocardiógrafo, Amplificador de instrumentación, Comunicación inalámbrica, electrocardiograma, Firmware.

\begin{abstract}
$\mathrm{A}$ $\mathrm{n}$ electrocardiograph is an instrument used to detect and diagnose heart's function abnormalities. Besides its high cost, in our country it is hard to find a portable instrument which make difficult to collect data about the heart's cardiac rhythm while a patient is being translated to a hospital or when a frequent monitoring of the heart is needed. This paper describes the methodology followed and the obtained results in the development of an electrocardiograph capable of recording and transmitting data, using the Bluetooth communication protocol, to a computer. Microcontroller technology was used to implement the electrocardiograph and LABVIEW to develop the program to receive and process data in order to show the electrocardiogram in the computer screen. Data are stored in an EEPROM memory for further analysis.
\end{abstract}

Keywords: Instrumentation amplifier, Wireless communication, electrocardiogram, firmware 